\section{References}

BEATS, B., BAGLEY, G., BANKS, V., et al (1992) Higher training in old age psychlatry: a survey of senior registrars experiences. Psychiatric Bullettr, 16, 622-624.

BENBOw, S. \& JoLEY, D. (1993) All work? A day in the life of geriatric psychlatrists. International Joumal of Gerlatric Psychlatry. 8, 1019-1022.
COPELAND, J. (1992) Higher training: what is it trying to achieve and what is its rationale? Psychiatric Bullettr. 16. 391-395.

Michael Philpot, Consultant in Old Age Psychiatry, Maudsley Hospital, Denmark Hill, London SE5 8AZ

\title{
Newly appointed consultants in old age psychiatry and the adequacy of higher training
}

\author{
Ruth Loane and Andrew Barker
}

\begin{abstract}
This paper reports on a survey of nowty appointed consultionts in old age poychiatry. The questionnaire aiked for opinions on the adequacy of higher froining in a number of areas such as clinical, manogement, teaching, supervition and resecorch. In addition vbows were sought on particulaty valuctible experiences in preparation for consullancy. The results show that overell cliniced fraining wos judged to be good, while troining in some non-clinical crecs, eapectally manogement, wos found to be inauilicient. The importance of manogement training ts emphastsed and some valuable troining experiences are highilighted.
\end{abstract}

It is essential for old age psychiatry services to have consultants who have been adequately prepared for the role which includes organisation of the service, clinical practice, education and research (Arie \& Jolley, 1982). Some newly appointed consultants have expressed the view that areas of their work were insufficiently covered during their higher training. In order to investigate this further the Senior Registrar Group of the Section of Old Age Psychiatry carried out a survey of newly appointed consultants in old age psychiatry to assess adequacy of training in a number of areas.

\section{The study}

In 1994, 43 newiy appointed (within the previous five years) consultants were identified through the Section of Old Age Psychiatry and a questionnaire was sent to each of them. The questionnaire covered length of higher training. clinical, management, research and teaching experience and additional areas, such as supervision and recruitment. Further comments and suggestions were encouraged, for example on ways in which higher training might be improved, or particularly valuable training experiences.

\section{Findings}

Thirty-five $(81 \%)$ completed questionnaires were recetved from consultants who had experience of 15 training schemes from a wide geographical area. The average length of training was three and a half years and four respondents had completed part-time higher training.

\section{Clinical experience}

Table 1 shows the various areas of clinical experience that respondents had been exposed to during higher training and how good this experience was in preparing them for consultancy. Overall, clinical experience was felt to be satisfactory. Particularly valuable experience included a three-month locum, responsibility for a geographical area with minimal supervision, experience of working with geriatricians, liaison clinic in general practice surgery, and liaison with nursing/residential homes. 
Table 1.

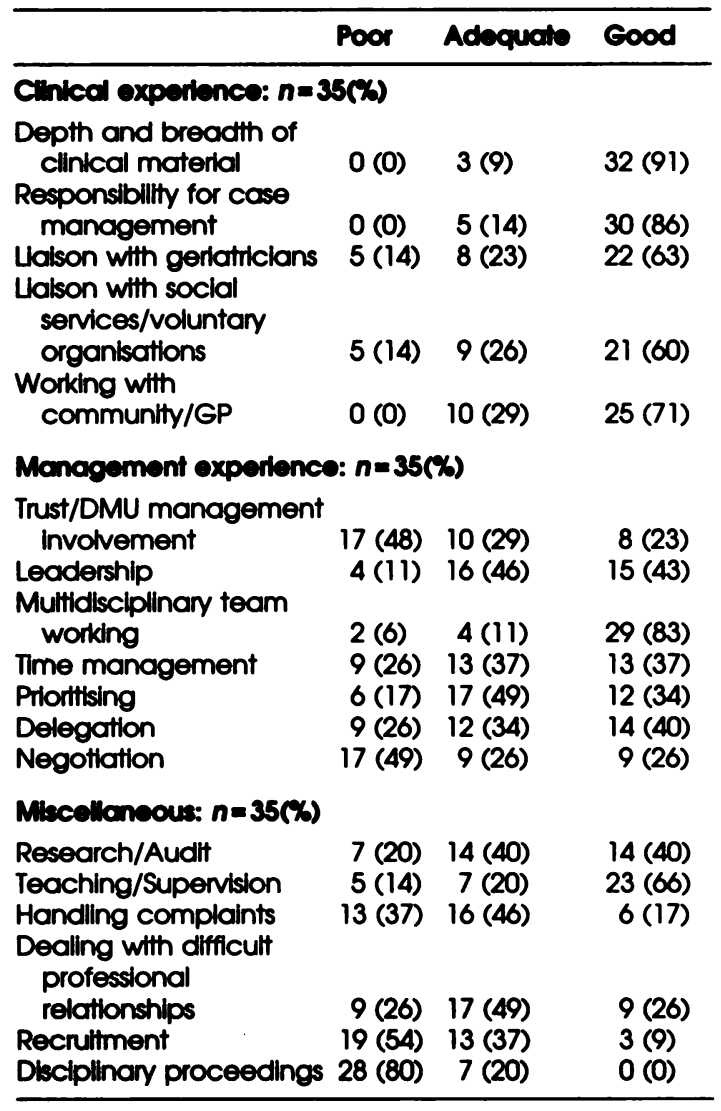

\section{Management experience}

Management experience was felt to be lacking in a number of areas (Table 1). Almost half (48\%) felt that experience in Trust/directly managed unit (DMU) management and training in negotiating skdlls was unsatisfactory. One-quarter were dissatisfied with training in time management, prioritising and delegation. Over three-quarters expressed the view that thetr experience in leadership was adequate or good in training them for consultancy. Useful training experiences included a management course, attachment to key hospital manager, involvement in a project (e.g. setting up a community mental health team), and locum consultant experience. Suggested additional, benefictal training experiences included delegation by consultant trainers of some part of their management role to the senior registrar and participation in senior house officer (SHO)/registrar appointment committees.

\section{Miscellaneous}

Just over three-quarters (80\%) of respondents felt their higher training experience in research had at least adequately prepared them for their consultant's role, though some expressed diffculty in obtaining supervision for research. Three-quarters found their experience in teaching satisfactory but additional comments recorded that often there was "plenty of experience but little guidance or feedback". Particularly weak areas were training and experience in handling complaints, dealing with difficult professional relationships, recruitment and disciplinary proceedings (Table 1).

Supervision was available to all but one respondent, and over three-quarters (78\%) found it to be useful. Just less than half (48\%) did not recetve an individual performance review. Twothirds (68\%) had had responsibility for a geographical area, and all stated that they found this helpful in preparation for consultancy. Threequarters had locum consultant experlence prior to appointment to a substantive consultant post and over three-quarters of these confirmed that it was very useful training.

\section{Comment}

Unfortunately the College does not keep a list of the date of appointment of consultants, so the recruitment necessitated the use of contacts from within the Section of Old Age Psychiatry. However, a large number of training schemes over a wide geographical area were represented. As every consultant's appointments committee has a College representattve, perhaps it would be possible for the College to keep a list of appointed consultants and the date of their appointment.

Clinical experience in a wide variety of settings has rightly been emphasised and was generally felt to be adequate in preparation for the clinical role of the consultant in old age psychiatry. Suggested additions to higher training include responsibility for sector area with minimal supervision and locum consultant experience. These options give the higher trainee consultant experience either with minimal supervision or for a short period, thereby creating opportunities to put into practice those skills already learned and identify gaps in their own training which need to be addressed; such an experience provides the trainee with improved knowledge of, and preparation for, a consultant's role and workload.

Supervision was widely available, and also was valued as a resource. This is in contrast to that found by Beats et al (1992) where supervision was found lacking by some respondents. Only half of the respondents had the experience of individual 
performance review which was felt to be a useful addition to supervision and is something which could easily be incorporated into a training scheme. The lack of guidance and feedback on teaching is a cause for concern as this does form part of a consultant's workload who also needs to be able to teach others to teach.

The main area of higher training which would appear to need addressing is management training. This could be by a combination of both formal and informal means. These would include management courses and, for example, shadowing a hospital manager or having some management responsibility being delegated from the trainer to the trainee. The respondents in this study had been appointed consultants over the past five years and higher training may have changed over this time - in particular management training, as there is more emphasis now on management in the role of the consultant (Harrison, 1992).

\section{References}

ARIE, T. \& JOLLY, D. (1982) Making services work: organisation and style of psychogerlatric services. In The Psychiatry of Late Life (eds R. Levy \& F. Post). London: Blackwell Scientific Publications.

BEATS, B., BAGLEY, G., BANKS, V., et al (1992) Higher training in old age psychlatry: a survey of senior registrars' experiences. Psychiatric Bulletin, 16, 622-624.

HARRISON, S. (1992) Management and doctors. In Management Training for Psychiatrists (eds D. Bhugra \& A. Burns), pp. 33-43. London: Gaskell.

*Ruth Loane, Senior Registrar in Old Age Psychiatry, St Charles Hospital, London W10 6DZ; and Andrew Barker, Senior Registrar, The Old Manor Hospital, Wiltshire SP2 7EP

*Correspondence

On behalf of the Senior Registrar Group of the Section of Old Age Psychiatry

\title{
Gaskell Academic Series
}

\section{Interpersonal Factors in Origin and Course of Affective Disorders}

\author{
Edited by $\mathrm{Ch}$. Mundt, with the assistance of Hugh Freeman
}

This detailed overview of the latest research on affective disorders brings together authors of international background and repute. Both a theoretical and practical approach to the origin and course of affective disorders is presented, covering specific problems and settings. The principal areas covered are: personality factors, risk and course; social support; marital and family interaction; and intervention.

• £25.00 • 396pp. • Hardback • 1995 • ISBN 1902241907

Available from bookshops and from the Publications

Department, Royal College of Psychiatrists, 17 Belgrave Square,

London SW1X 8PG (Tel. 0171-235 2351, extension 146) 